\title{
COLD COMFORT
}

Mothers, Professionals, and

Attention Deficit Disorder

Mothers of children with attention deficit (hyperactivity) disorder must inevitably make decisions regarding their children's diagnosis within a context of competing discourses about the nature of the disorder and the legitimacy of its treatment. They also make these decisions within an overriding climate of mother-blame. Claudia Malacrida's Cold Comfort provides a contextualized study of how mothers negotiate with/against the 'helping professions' over assessment and treatment for their children.

Malacrida counters current conceptions about mothers of ADD/ ADHD children (namely that mothers irresponsibly push for Ritalin to manage their children's behaviour) as well as professional assumptions of maternal pathology. This thought-provoking examination documents Malacrida's extensive interviews with mothers of affected children in both Canada and the United Kingdom, and details the way in which these women speak of their experiences. Malacrida compares their narratives to national discourses and practices, placing the complex mother-child and mother-professional relations at the centre of her critical inquiry.

Drawing on both poststructural discourse analysis and feminist standpoint theory, Malacrida makes a critical contribution to qualitative methodologies by developing a feminist discursive ethnography of the construction of ADD/ADHD in two divergent cultures. On a more personal level, she offers readers a moving, nuanced, and satisfying examination of real women and children facing both public and private challenges linked to ADD/ADHD.

CLAUDIA MALACRIDA is an assistant professor in the Department of Sociology at the University of Lethbridge. 
This page intentionally left blank 


\section{COLD COMFORT}

Mothers, Professionals, and Attention Deficit Disorder

Claudia Malacrida

UNIVERSITY OF TORONTO PRESS Toronto Buffalo London 
www.utppublishing.com

(C) University of Toronto Press Incorporated 2003

Toronto Buffalo London

Printed in Canada

ISBN 0-8020-8752-3 (cloth)

ISBN 0-8020-8558-X (paper)

(6)

Printed on acid-free paper

National Library of Canada Cataloguing in Publication

Malacrida, Claudia, 1953-

Cold comfort : mothers, professionals, and attention deficit disorder / Claudia Malacrida.

Includes bibliographical references and index. ISBN 0-8020-8752-3 (bound) ISBN 0-8020-8558-X (pbk.)

1. Attention-deficit-disordered children. 2. Mother and child.

3. Mothers-Interviews. 4. Attention-deficit hyperactivity disorder - Diagnosis - Cross-cultural studies. 5. Attention-deficit hyperactivity disorder - Treatment - Cross-cultural studies.

I. Title.

RJ506.H9M34 $2003 \quad 306.874^{\prime} 3 \quad$ C2003-900681-6

This book has been published with the help of a grant from the Canadian Federation for the Humanities and Social Sciences, through the Aid to Scholary Publications Programme, using funds provided by the Social Sciences and Humanities Research Council of Canada.

University of Toronto Press acknowledges the financial assistance to its publishing program of the Canada Council for the Arts and the Ontario Arts Council.

University of Toronto Press acknowledges the financial support for its publishing activities of the Government of Canada through the Book Publishing Industry Development Program (BPIDP). 
For Hilary 
This page intentionally left blank 